${ }^{3}$ Bodansky, O., and Schwartz, M. K., J. Biol. Chem., 238, 3420 (1963).

${ }^{4}$ Campbell, D. M., Biochem. J., 82, 34P (1962).

s Schwartz, M. K., and Bodansky, O., Cancer, 18, 886 (1965).

${ }^{6}$ Hill, P. C., and Sammons, H. G., Quart. J. Med., 36, 457 (1967)

' Walker, P. G., and Bayliss, V., Proc. Sixth Intern. Cong. Clinical Chemistry, 180 (1966)

${ }^{8}$ Ipata, P. L., Anal. Biochem., 20, 30 (1967).

' Heppel, L. A., and Hilmoe, R. J., J. Biol. Chem., 188, 665 (1951).

${ }^{10}$ Hardonk, M. J., Histochemie, 12, 1 (1968).

1t Reis, J, X, Biochem. J., 48, 548 (1951).

${ }^{12}$ Widuell, C. C., and Tata, J. R., Biochem. J., 92, 313 (1964).

${ }^{13}$ King, E. J., Haslewood, G. A. D., Delory, G. E., and Beall, D., Lancet, i, 207 (1.942).

is Volkin, E., in Methods in Enzymology, 2 (edit. by Colowick, S. P., and Kaplan, N. O.), 539 (Academic Press, New York, 1955).

${ }^{15}$ Kowlessar, O. D.s Haeffner, L. J., Riley, E. M., and Sleisenger, M. H., Amer, J. Med., 31, 231 (1961).

${ }^{16}$ Vinnick, I. E., Kern, F., and Corley, W. D., Gastroenterology, 45, 492 (1963).

1: Schwartz, M. K., and Bodansky, O., Amer. J. Clin. Pathol., 42, 572 (1964).

\section{Effect of Epidermal Chalone on Human Epidermal Mitotic Activity in vitro}

ExTRACTS of vertebrate epidermis contain an antimitotic chemical messenger, called the epidermal chalone, which seems to be important in the control of epidermal mitosis ${ }^{1}$. Although the epidermal chalone is known to be tissuespecific, it is neither species nor class-specific. Chalone extracted from human skin has been found to be active on mouse epidermis ${ }^{1}$, but no experiments have yet tested the effects of skin extracts on human epidermis.

Pieces of human skin, about $10-15 \mathrm{~cm}$ long and $1-$ $1.5 \mathrm{~cm}$ wide, were obtained during abdominal operations, and immediately immersed in cold sterile saline. The subcutaneous adipose tissue was eut away, and the epidermis with the upper part of the corium was removed from the skin with a Castrovieijo keratotome. These slices $(0.6 \mathrm{~mm}$ thick) were floated on the surface of Hanks balanced salt solution, and a piece of sterile paper to which the skin easily adhered was placed underneath. The paper was then laid on "black paraffin" (50 per cent carbo medicinale and 50 per cent paraffin, melted together in a Petri dish and heat sterilized) and cut into small pieces, about $4 \times 4 \mathrm{~mm}$. When floated on Hanks solution once more, the paper sank and the skin floated. The pieces of skin were placed on a stainless steel grid in plastic culture dishes filled with sufficient nutrient medium to cover the grids, but not the skin.

The nutrient medium consisted of Parker's solution 199, human $\mathrm{AB}$ serum, and chicken embryo extract $(6: 2: 2)$. Neomycin was used as an antibiotic. The dishes were placed in an airtight box which was gassed with a mixture of 5 per cent carbon dioxide and 95 per cent oxygen. The pieces of skin were incubated for 4 days at $37^{\circ} \mathrm{C}$; the medium was changed after 2 days. This procedure was found to be necessary, for only after 4 days did the epidermal mitotic rate recover sufficiently for reliable counts to be made. By this time, in almost all pieces of skin, the epidermis had moved round to encapsulate the dermis ${ }^{2}$, while at the edges there was a thick rim of degenerate (parakeratotic) epithelial cells.

The pieces of skin were divided into two groups, $A$ and $B$, the latter being the control group. Both groups were given 'Colcemid' $(0.01 \mathrm{ml}$. of a 1 per cent solution $/ 2.5 \mathrm{ml}$. of medium). We carried out some preliminary experiments to determine whether the epidermal chalone could exert any effect without pretreatment with adrenaline. We found no difference between cultures treated with "liver chalone" (discussed later) or with epidermal chalone. This confirmed the observation that epidermal chalone has no specific antimitotic effect when adrenaline is not present ${ }^{1}$. One hour after the start of 'Colcemid' treatment, all pieces of skin were therefore given a $5 \mathrm{~min}$ wash in a Petri dish containing $0.5 \mu \mathrm{g}$ of adrenaline $/ \mathrm{ml}$., and in experiment 9 hydrocortisone $(2.5 \mu \mathrm{g} / \mathrm{ml}$.) was added with the adrenaline. Then the pieces of skin were returned to their culture dishes containing the same medium with 'Colcemid'. To group $A$ skins, skin extracts from either mice or pigs were added. In the first three experiments group $B$ skins were given one drop of saline, while in the last six experiments with group $B$ skins extracts of pig liver (prepared exactly like the mouse skin extracts) were added. The epidermal chalone was extracted from pig skin by N. V. Organon (Oss, The Netherlands) and was partly purified after precipitation with 70-80 per cent alcohol. Chalone from mouse skin was prepared in our laboratory and was not purified, but only lyophilized. Each culture was given a dose of chalone (from skin or from liver) corresponding to a protein content of $5 \mathrm{mg} / \mathrm{ml}$. Four hours after the initial addition of 'Colcemid', that is, after $3 \mathrm{~h}$ of chalone action, all the pieces of skin were fixed in Bouin's solution for at least $4 \mathrm{~h}$. After embedding in paraffin, sections $5 \mu$ thick were cut. Twentyfour explants were used in each experiment, twelve in group $A$ and twelve in group $B$. In each group $16 \times 40$ vision fields were counted. In each experiment the numbers of mitoses have thus been scored among 48,000 cells in the chalone treated groups, and 48,000 cells in the control groups.

Table 1. EFFEOT OF CHALONE ON HUMAN SKIN in vitro Mitotic count per 1,000 cells after $1 \mathrm{~h}$

\begin{tabular}{|c|c|c|c|c|c|}
\hline \multirow{3}{*}{$\begin{array}{l}\text { Source } \\
\text { of } \\
\text { chalone }\end{array}$} & \multirow{3}{*}{$\begin{array}{c}\text { Experi- } \\
\text { ment } \\
\text { No. }\end{array}$} & \multicolumn{3}{|c|}{ 'Colcemid', 5 min adrenaline and then } & \multirow{3}{*}{$\begin{array}{l}\text { Percentage } \\
\text { depression of } \\
\text { mitotic rate }\end{array}$} \\
\hline & & & Liver & $\begin{array}{l}\text { 1alone } \\
\text { Epidermal }\end{array}$ & \\
\hline & & $\begin{array}{l}\text { Saline } \\
\text { added** }\end{array}$ & $\begin{array}{l}\text { extract } \\
\text { added* }\end{array}$ & $\begin{array}{l}\text { chalone } \\
\text { added** }\end{array}$ & \\
\hline \multirow[t]{3}{*}{ Pig } & 1 & $7 \cdot 4 \pm 0 \cdot 70$ & 一 & - & \\
\hline & $\frac{2}{3}$ & $\begin{array}{r}7 \cdot 8 \pm 1 \cdot 00 \\
10 \cdot 1 \pm 1 \cdot 27\end{array}$ & 二 & $\begin{array}{l}4 \cdot 5 \pm 0 \cdot 60 \\
5 \cdot 1 \pm 0 \cdot 66\end{array}$ & $\left.\begin{array}{l}58 \\
50\end{array}\right\}$ Mean 54 \\
\hline & $\begin{array}{l}4 \\
5\end{array}$ & - & $\begin{array}{l}8 \cdot 0 \pm 0 \cdot 77 \\
5 \cdot 4 \pm 0 \cdot 74\end{array}$ & $\begin{array}{l}5 \cdot 7 \pm 0 \cdot 57 \\
2 \cdot 7 \pm 0.43\end{array}$ & $\left.\begin{array}{l}29 \\
50\end{array}\right\}$ Mean 40 \\
\hline Mouse & $\begin{array}{l}6 \\
7 \\
8 \\
9 \dagger\end{array}$ & $=$ & $\begin{array}{l}4 \cdot 1 \pm 0.44 \\
7.7 \pm 0.85 \\
6 \cdot 8 \pm 0 \cdot 78 \\
5 \cdot 4 \pm 0.59\end{array}$ & $\begin{array}{l}2 \cdot 2 \pm 0 \cdot 31 \\
3 \cdot 5 \pm 0 \cdot 62 \\
3 \cdot 4 \pm 0 \cdot 68 \\
2 \cdot 6 \pm 0 \cdot 24\end{array}$ & $\left.\begin{array}{l}46 \\
55 \\
50 \\
52\end{array}\right\}$ Mean 51 \\
\hline
\end{tabular}

* Values are mean mitotic counts from a total of 48,000 cells scored \pm standard errors of the mean using the number of explants $(n=12)$ for calculation.

$\dagger$ In this experiment hydrocortisone was added together with the $5 \mathrm{~min}$ adrenaline wash.

Results are shown in Table 1. Extracts of liver depressed the human epidermal mitotic rate slightly, but not significantly. Compared with the control groups, chalone extracted from pig and mouse skin depressed the human mitotic rate by about 50 per cent. These observations confirm previous observations that watery extracts of epidermal tissue contain a mitotic inhibitor, or chalone, which is not species-specific in its action.

I thank Dr Hondius Boldingh for the pig skin chalone, Professor B. Fretheim for the pieces of human skin, Professor W. S. Bullough for advice and help, and Miss Kirsten Huser for technical assistance.

Olav Hilmar Iversen

Institute of General and Experimental Pathology,

University of Oslo,

Norway.

Received April 2; revised May 2, 1968.

${ }^{1}$ Bullough, W. S., Laurence, E. B., Iversen, O. H., and Elgjo, K., Nature, $214,578(1967)$.

${ }^{2}$ Chang, L. W., and Maibach, H. I., J. Invest. Derm., 49, 486 (1967),

\section{Survival after Fractionated Doses of Radiation: Modification by Anoxia of the Response of Chlamydomonas}

IF ionizing radiation is delivered in fractions, cells usually recover from "sub-lethal damage" inflicted by one dose during the time which elapses before the next dose is given. This phenomenon has been observed with many types of cell, ranging from micro-organisms to higher 